\title{
Pathogenicity and a TaqMan Real-Time PCR for Specific Detection of Pantoea allii, a Bacterial Pathogen of Onions
}

\author{
Shabnam Rahimi-Khameneh, ${ }^{1}$ Sanni Hsieh, ${ }^{1}$ Renlin Xu, ${ }^{1}$ Tyler J. Avis, ${ }^{2}$ Sean Li, ${ }^{3}$ Donna Smith, ${ }^{3}$ Bhabesh Dutta, ${ }^{4}$ Ronald D. Gitaitis, ${ }^{4}$ \\ and James T. Tambong ${ }^{1, \dagger}$ \\ ${ }^{1}$ Ottawa Research and Development Centre, Ottawa, Ontario K1A 0C6, Canada \\ ${ }^{2}$ Department of Chemistry, Carleton University, Ottawa, Ontario, Canada \\ ${ }^{3}$ Canadian Food Inspection Agency, Charlottetown, Prince Edward Island, Canada \\ ${ }^{4}$ Department of Plant Pathology, College of Agricultural and Environmental Sciences Campus, University of Georgia, Tifton, \\ GA 31793, U.S.A.
}

\begin{abstract}
Bacterial diseases of onion are reported to cause significant economic losses. Pantoea allii Brady, one of the pathogens causing the center rot on onions, has not yet been reported in Canada. We report the pathogenicity of $P$. allii on commercially available Canadian green onions (scallions). All P. alliiinoculated plants, irrespective of the inoculum concentration, exhibited typical leaf chlorotic discoloration on green onion leaves, which can reduce their marketability. Reisolation of $P$. allii from infected scallion tissues and reidentification by sequencing and phylogenetic analyses of the leuS gene suggest that the pathogen can survive in infected tissues 21 days after inoculation. This is the first report of $P$. allii as a potential pathogen of green onions. This study also reports the development and validation of a TaqMan real-time PCR assay targeting the leuS gene for reliable detection of $P$. allii

using 61 bacterial and fungal strains. Under optimal conditions, the selected primers and FAM-labeled TaqMan probe were specific for the detection of nine reference $P$. allii strains by real-time PCR. The 52 strains of other Pantoea spp. $(n=25)$, non-Pantoea spp. $(n=20)$, and fungi/oomycetes $(n=7)$ tested negative (no detectable fluorescence). Onion tissues spiked with $P$. allii, naturally infested onion bulbs, greenhouse infected green onion leaf samples, as well as an interlaboratory blind test were used to validate the assay specificity. The sensitivities of a 1-pg DNA concentration and $30 \mathrm{CFU}$ are comparable to previously reported real-time PCR assays of other bacterial pathogens. The TaqMan real-time PCR assay developed in this study will facilitate reliable detection of $P$. allii and could be a useful tool for screening onion imports or exports for the presence of this pathogen.
\end{abstract} in pure cultures and in planta. A 642-bp leuS gene fragment was targeted because it showed high nucleotide diversity and positively correlated with genome-based average nucleotide identity with respect to percent similarity index and identity of Pantoea species. The assay specificity was validated
Keywords: disease development and spread, epidemiology, fluorescent probes, pathogen survival, pathogen detection, prokaryotes, techniques, vegetables
Alliums (bulb onion and scallions) are vegetables commonly consumed worldwide (Opara 2003). In Canada, most onions originate from Ontario and Quebec, with 45 and 37\% of crop land, respectively (Agriculture and Agri-Food Canada 2012). In 2012, Canada exported about CAD $\$ 140$ million and imported CAD $\$ 22$ million worth of onions (Agriculture and Agri-Food Canada 2012). The movement of agricultural produce such as onions across international borders has an inherent risk of spreading prevalent or new diseases into new habitats. It is crucial that onion production in Canada is protected against new diseases that might reduce the market quality with economic loss to growers.

Bacterial diseases of onion caused by Pantoea ananatis and P. agglomerans have been reported in the United States and South Africa (Edens et al. 2006; Gitaitis and Gay 1997; Hattingh and Walters 1981) with potentially significant economic losses (Hattingh and Walters 1981; Walcott et al. 2002). In 2004, a new pathogenic Pantoea strain was isolated from onions in South Africa. Taxonomic study based on amplified fragment length polymorphism, 16S rRNA sequence similarity, and whole-genome DNA-DNA relatedness confirmed the

${ }^{\dagger}$ Corresponding author: J. T. Tambong; james.tambong@ canada.ca

Funding: Funding was provided by Agriculture and Agri-Food Canada through project numbers J-001012, J-000409, and J-00985.

*The $\boldsymbol{e}$-Xtra logo stands for "electronic extra" and indicates that one supplementary figure is published online.

The author(s) declare no conflict of interest.

Accepted for publication 5 July 2019

() Her Majesty, the Queen in Right of Canada through the Minister of Agriculture and Agri-Food Canada, 2019. classification of the strain as novel species, $P$. allii (Brady et al. 2011). This study also included Pantoea strains from the United States collected from fields with center rot incidence, which were later confirmed as $P$. allii. Center rot incidence associated with $P$. allii has not been reported in Canada. Precautionary measures are required to prevent infected onion imports from introducing $P$. allii into Canada.

$P$. allii is phylogenetically related to $P$. ananatis (Goszczynska et al. 2006; Palmer et al. 2017; Tambong et al. 2014). P. allii is a facultative anaerobic, Gram-negative, nonspore-forming, noncapsule rod-shaped bacterium (Brady et al. 2010, 2011). Its pathogenicity to green onions and other Allium spp. grown in Canada has not been reported, so it is important to determine whether this bacterium can infect commercially available green onions.

Furthermore, there is currently no reliable molecular assay for specific identification and detection of $P$. allii on onion plants as well as in pure cultures, given that it is a relatively new pathogen. A conventional PCR assay based on an $16 \mathrm{~S}$ to $23 \mathrm{~S}$ rRNA internal transcribed spacer developed to detect $P$. ananatis also produces a 389-bp amplicon with $P$. allii (Figueiredo and Paccola-Meirelles 2012). This seems to be the only publicly available molecular tool for detection of $P$. allii. The differentiation between $P$. ananatis $(389 \mathrm{bp}$ ) and $P$. ailli $(361 \mathrm{bp})$ strains using this PCR-based assay relies on a 28-bp difference in amplicon length (Figueiredo and Paccola-Meirelles 2012). An agarose gel electrophoretic separation of PCR amplicons that differ by only 28 bp can be a challenge, leading to potential misidentification. In addition, the conventional PCR-based technique requires post-PCR handling to visualize the results for identification and as such is prone to errors. Alternatively, TaqMan real-time PCR minimizes some of these inherent problems while providing accurate detection and identification of specific plant pathogens (Robène et al. 2015; Tambong et al. 2008, 2016; $\mathrm{Xu}$ and Tambong 2011). Because post-PCR processing steps are not required, real-time PCR can be easily automated with high sample throughput and specificity (Tambong et al. 2016; Weller et al. 2000). 
The objectives of this research were to (i) evaluate the reliability of using a 642-bp leuS gene fragment for differentiation of $P$. allii from its closest phylogenetic Pantoea species relative to genome-based parameters, (ii) develop and validate a TaqMan-based real-time PCR assay for specific detection and/or identification of $P$. allii based on the leuS gene, and (iii) conduct a pathogenicity study on commercially available Canadian green onion (scallions) plants. A housekeeping gene, leuS, was targeted for the development of the assay because it was reported to be a reliable phylogenetic marker (Tambong et al. 2014). The molecular tool developed in this study could be used by regulatory agencies to screen onion imports for this pathogen.

\section{Materials and Methods}

Genomic DNA extraction, PCR gene amplification, and sequencing. Bacterial strains (Table 1) were cultured overnight at $28^{\circ} \mathrm{C}$ in Luria-Bertani (LB) broth (per liter of $\mathrm{H}_{2} \mathrm{O}: 10 \mathrm{~g}$ of tryptone, $5 \mathrm{~g}$ of yeast extract, and $10 \mathrm{~g}$ of $\mathrm{NaCl}$; $\mathrm{BD}$ Canada) and genomic DNA was extracted and purified using the Wizard SV Genomic DNA Purification System Kit (Promega) following the manufacturer's protocols. The DNA was quantified using picogreen chemistry in FLUOstar (BMG Labtech) and stored at $-20^{\circ} \mathrm{C}$. Genus-based and species-level identification of $P$. allii was performed as previously reported (Tambong et al. 2014) using 16S rRNA and leuS

Table 1. Bacterial strains used in this study



y The superscript "T" denotes type strain.

${ }^{\mathrm{z}}$ Strains were obtained from the following culture collections: $\mathrm{LMG}=$ Laboratium voor Microbiologie at Rijs Universiteit $(\mathrm{Gent}, \mathrm{Belgium}), \mathrm{CFBP}=\mathrm{Plant}$ Associated Bacteria Collection (France), NCPPB = National Collection of Plant Pathogenic Bacteria (United Kingdom), GSPB = Braunshweig, Germany, DSM $=$ German Collection of Microorganisms and Cell Cultures GmbH, ATCC $=$ American Type Culture Collection, and CCFC $=$ Canadian Collection of Fungal Cultures. 
sequencing followed by BLAST (Altschul et al. 1990) and phylogenetic analyses.

Genome sequencing and analyses. The reliability of using a 642-bp leuS gene fragment relative to genome-based analysis for differentiation of $P$. allii from its closest phylogenetic Pantoea species parameter was evaluated. We generated a de novo genome sequence of $P$. allii LMG $24248^{\mathrm{T}}$ because the available GenBank entry with accession number MLFE00000000 has an extremely high number of pseudogenes; data for 14 additional genomes were retrieved from GenBank (Table 2). The draft genome of $P$. allii $24248^{\mathrm{T}}$ was determined by the Génome-Québec Innovation Centre in Montreal, Quebec, Canada, using Illumina MiSeq paired-end sequencing technology, and the raw reads were assembled as previously described (Adam et al. 2014; Tambong et al. 2016). The whole genome shotgun project was deposited in GenBank under accession number NTMH00000000. Genome-based average nucleotide identity (ANI) values were computed using the OrthoANIu algorithm (Yoon et al. 2017). In addition, the 642-bp leuS gene fragments of all 14 Pantoea species were downloaded and pairwise percent identity (BLAST) was performed using CLC Genomic Workbench version 12 (Bio-Rad). The relationship between leuSbased percent nucleotide identity (LNI) and ANI was determined by Pearson correlation analysis using the cor.test function in Rcore (R Core Team 2014).

Table 1. (Continued from previous page)

\begin{tabular}{|c|c|c|c|}
\hline Species/strain ${ }^{y}$ & Host & Origin & Source $^{\mathrm{z}}$ \\
\hline DOAB 021 & Corn & Canada & J. Tambong \\
\hline DOAB 022 & Corn & Canada & J. Tambong \\
\hline \multicolumn{4}{|l|}{ P. theicola } \\
\hline LMG $29103^{\mathrm{T}}$ & Black tea in processing & Japan & LMG \\
\hline \multicolumn{4}{|l|}{ P. vagans } \\
\hline LMG $24199^{\mathrm{T}}$ & Eucalyptus & Uganda & LMG \\
\hline \multicolumn{4}{|l|}{ P. wallisii } \\
\hline LMG $26277^{\mathrm{T}}$ & Eucalyptus & South Africa & LMG \\
\hline \multicolumn{4}{|l|}{ Non-Pantoea } \\
\hline \multicolumn{4}{|l|}{ Bacillus subtilis } \\
\hline CH15 & Soybean roots & Canada & A. Xue \\
\hline $\mathrm{CH} 10$ & Soybean roots & Canada & A. Xue \\
\hline \multicolumn{4}{|l|}{ Clavibacter michiganesis } \\
\hline NCPPB $2979^{\mathrm{T}}$ & Tomato & Hungary & NCPPB \\
\hline \multicolumn{4}{|l|}{ C. nebraskensis } \\
\hline NCPPB $2581^{\mathrm{T}}$ & Corn & United States & NCPPB \\
\hline DOAB 395 & Corn & Canada & J. Tambong \\
\hline DOAB 397 & Corn & Canada & J. Tambong \\
\hline \multicolumn{4}{|l|}{ Dickeya dadantii } \\
\hline 340 & S. tuberosum & Peru & E. French \\
\hline GSPB413 & Chrysanthemum sp. & United States & W. H. Burkholder \\
\hline \multicolumn{4}{|l|}{ Pectobacterium carotovora } \\
\hline Ecc26 & Unknown & Canada & S. H. De Boer \\
\hline Ecc71 & Unknown & Canada & S. H. De Boer \\
\hline \multicolumn{4}{|l|}{ Pseudomonas azotoformans } \\
\hline LMG $21611^{\mathrm{T}}$ & Japanese unhulled rice & Japan & LMG \\
\hline \multicolumn{4}{|l|}{ Pseudomonas poae } \\
\hline LMG $21465^{\mathrm{T}}$ & Grasses, phyllosphere & Germany & LMG \\
\hline \multicolumn{4}{|l|}{ Pseudomonas trivialis } \\
\hline LMG $21464^{\mathrm{T}}$ & Grasses, phyllosphere & Germany & LMG \\
\hline \multicolumn{4}{|l|}{ Pseudomonas congelans } \\
\hline DSM $14939^{\mathrm{T}}$ & Grasses, phyllosphere & Germany & DSM \\
\hline \multicolumn{4}{|l|}{ Streptomyces acidiscabies } \\
\hline ATCC 49003 & Unknown & Unknown & ATCC \\
\hline \multicolumn{4}{|l|}{ S. scabies } \\
\hline CG1 & Potato & Canada & C. Beaulieu \\
\hline \multicolumn{4}{|l|}{ Xanthomonas sp. } \\
\hline PDY-0703 & Tomato & Canada & D. Cuppels \\
\hline & Tomato & Canada & D. Cuppels \\
\hline \multicolumn{4}{|c|}{ Xanthomonas campetris pv. campetris } \\
\hline XCC00-1 & Cabbage & United States & R. Walcott \\
\hline \multicolumn{4}{|l|}{ Burkholderia cepacia } \\
\hline $\mathrm{Bc} \mathrm{BA} 7$ & Unknown & Turkey & D. Cuppels \\
\hline Bc BA8 & Unknown & Turkey & D. Cuppels \\
\hline \multicolumn{4}{|l|}{ Fungal/oomycete pathogens } \\
\hline Rhizoctonia solani & Soil & Canada & $\mathrm{CCFC}$ \\
\hline Pythium ultimum & Tomato & Canada & CCFC \\
\hline Pythium arrhenomanes & Corn roots & Canada & $\mathrm{CCFC}$ \\
\hline Aspergillus niger KAS2044 & Unknown & Canada & K. Siefert \\
\hline Botrytis squamosa KAS2264 & Unknown & Canada & K. Siefert \\
\hline Botrytis sp. KAS1817 & Unknown & Canada & K. Siefert \\
\hline Botrytis sp. KAS1818 & Unknown & Canada & K. Siefert \\
\hline
\end{tabular}


Primers and TaqMan probe design and real-time PCR conditions. The leuS gene was identified as a candidate for TaqMan probes based on high nucleotide variation across the genus Pantoea (Tambong et al. 2014). The leuS sequences of all publicly available Pantoea species were downloaded or extracted from GenBank and aligned using the Cluster W method (Thompson et al. 1994) as implemented in MegAlign (version 7.0; DNASTAR). Specific primers and dual-labeled TaqMan probes were designed (Tambong et al. 2016; Xu and Tambong 2011). A similarity search was performed using BLAST (Blastn, nucleotide versus nucleotide comparison) with the primers as queries against all publicly available GenBank nucleotide databases targeting the type strains as previously described (Tambong et al. 2006). In addition, a customized database comprising over 150 genomes of known bacterial and fungal pathogens of onion (https://www.apsnet.org/edcenter/resources/ commonnames/Pages/OnionandGarlic.aspx) was used to perform a similarity search using nucleotide sequences of the leu $\mathrm{S}$ fragment as the query. Primer-BLAST (Ye et al. 2012; https://www.ncbi. nlm.nih.gov/tools/primer-blast) with default parameters and the NCBI nucleotide (nr) database were also used to check the specificity of the primers and probe. The primers and probe were designed and analyzed for dimer or hairpin loop structures by using Oligo 6.71 software (Molecular Biology Insights, Cascade, CO). The following three primers were designed and evaluated for specificity: allii-leuS181F (5'-GTCCGGACACCTTCTATGGCGCAA-3'), alliileuS235R (5'-GGTTGCTTGCGGAAGCCTGCAGT-3'), and allii-leuS320R (5'-ATGTCAGCTTCAGCCACTTTGGTG-3'). A dual-labeled TaqMan probe, allii-leuS205pb (5'-[6 FAM]TACGTTGCCGTCGCGGCGGGCCA-[BHQ1]-3'), was designed and tested for specificity by BLAST (Tambong et al. 2016; Xu and Tambong 2011). Primers and probes were synthesized by SigmaAldrich (Oakville, ON, Canada), and the probe was labeled with the corresponding fluorescent reporter dyes. Preliminary evaluation of the two reverse primers (allii-leuS235R and allii-leuS320R) showed that the former produced more consistent fluorescent sigmoidal curves than the latter. As such, the reverse primer allii-leuS235R was selected for downstream study.

The optimal conditions for the TaqMan real-time PCR reaction, in a Chromo4 real-time PCR system (MJ Research Bio-Rad Laboratories, Mississauga, ON, Canada), start with an initial denaturation at $95^{\circ} \mathrm{C}$ for $10 \mathrm{~min}$, followed by 45 cycles of $95^{\circ} \mathrm{C}$ for $15 \mathrm{~s}$ and $60^{\circ} \mathrm{C}$ for $1 \mathrm{~min}$. Primer pair allii-leuS181F and allii-leuS235R and probe
allii-leuS205pb were used in real-time PCR reaction containing $5 \mu \mathrm{l}$ of $2 \times$ SsoAdvanced Universal Probes Supermix (Bio-Rad), $0.15 \mu \mathrm{l}$ of $20 \mu \mathrm{mol} / \mathrm{liter}$ of each primer, $0.15 \mu \mathrm{l}$ of $10 \mu \mathrm{mol} / \mathrm{liter}$ of probe, $1 \mu \mathrm{l}$ of template DNA, and $3.4 \mu \mathrm{l}$ of sterile ultrapure water to a total volume of $10 \mu \mathrm{l}$ (Tambong et al. 2008). Detection of the fluorescent emission was read after every cycle and data were assembled as previously reported (Tambong et al. 2008, 2016). Samples or standards were processed in triplicate including negative (water or no DNA template) and/or positive (type strain of $P$. allii) controls where necessary.

Sensitivity and specificity. Genomic DNA of $P$. allii strain LMG $24248^{\mathrm{T}}$ was serially diluted 10 -fold from $10 \mathrm{ng}$ to $10 \mathrm{fg}\left(10^{-5} \mathrm{ng}\right)$ in sterile nuclease-free water in order to determine the sensitivity (detection limit). The minimum number of colonies required for positive detection was determined using bacterial suspensions serially diluted in phosphate-buffered saline (PBS) nuclease-free water or from $10^{8}$ to $10^{2} \mathrm{CFU} / \mathrm{ml}$. The assay specificity was validated on genomic DNA of 61 bacterial and fungal strains, including 34 Pantoea strains, 20 non-Pantoea strains, and seven fungi/oomycetes (Table 1). DNA of all of the strains was diluted to $1 \mathrm{ng} / \mu \mathrm{l}$ and TaqMan real-time PCR was performed using the same conditions indicated above. Each strain was run in triplicate and repeated once including negative controls. In addition, four blind-coded samples (two $P$. allii [samples 1 and 2], one $P$. ananatis [sample 3], and one $P$. stewartii subsp. stewartii [sample 4]) were processed by a second laboratory (Canadian Food Inspection Agency, Charlottetown, PEI, Canada) to independently verify the reliability of the assay and to test its reproducibility on a different real-time PCR machine using the same conditions. This was done on a Rotor-Gene Q real-time PCR machine (Qiagen) and data were captured using Rotor-Gene $Q$ series software version 2.3.1 (Qiagen) and repeated once.

Pathogenicity test and in planta TaqMan real-time PCR detection of $\boldsymbol{P}$. allii. Commercially available green onion seedlings (A. fistulosum L. 'Green Bunching-Flavor King') were planted in potting soil $(0.5: 1: 1$ in Promix/black top soil/sand) in a growth chamber at $28^{\circ} \mathrm{C}$ with a $16-\mathrm{h} / 8-\mathrm{h}$ light/dark photoperiod. One seedling was planted per square fiber pot $(13.125 \mathrm{~cm}$ wide $\times 8.78 \mathrm{~cm}$ high; Ritchie, Canada). After 3 weeks, 15 plants having three to four leaves were selected for syringe inoculation at the lowest leaf close to the whorl region. $P$. allii LMG $24248^{\mathrm{T}}$ was grown in LB as indicated above. The bacterial broth was centrifuged at $10,625 \times g$ for $5 \mathrm{~min}$ and the supernatant was discarded. The pellet was resuspended in PBS.

Table 2. Values of genome-based average nucleotide identity (ANI) and leuS-based pairwise percent identity (LNI) of $P$. allii relative to 13 other Pantoea species

\begin{tabular}{|c|c|c|c|c|c|c|c|c|}
\hline Pantoea species $^{\mathrm{z}}$ & $\begin{array}{c}\text { Genome } \\
\text { accession no. }\end{array}$ & $\begin{array}{c}\text { Genome } \\
\text { size }(\mathrm{Mb})\end{array}$ & $\begin{array}{c}\text { Coding } \\
\text { sequences } \\
(n)\end{array}$ & $\begin{array}{l}\text { Contigs } \\
\quad(n)\end{array}$ & $\begin{array}{c}\text { Pseudogenes } \\
\text { (n) }\end{array}$ & $\begin{array}{l}\text { LNI } \\
(\%)\end{array}$ & $\begin{array}{c}\text { Genome- } \\
\text { based ANI } \\
(\%)\end{array}$ & Reference \\
\hline P. allii $\mathrm{LMG} 24248^{\mathrm{T}}$ & NTMH00000000 & 5.24 & 4,722 & 57 & 159 & 100.00 & 100.00 & This study \\
\hline P. allii $\mathrm{LMG} 24248^{\mathrm{T}}$ & MLFE00000000 & 5.01 & 4,114 & 92 & 519 & 100.00 & 99.96 & Palmer et al. (2017) \\
\hline P. ananatis $\mathrm{LMG} 2665^{\mathrm{T}}$ & JFZU00000000 & 4.98 & 4,486 & 27 & 114 & 89.41 & 88.65 & Adam et al. (2014) \\
\hline $\begin{array}{l}P \text {. stewartii subsp. } \\
\text { indologenes LMG } \\
2632^{\mathrm{T}}\end{array}$ & JPKO00000000 & 4.68 & 3,936 & 35 & 247 & 88.01 & 84.33 & Du Plessiss (unpublished data) \\
\hline $\begin{array}{l}\text { P. stewartii subsp. } \\
\text { stewartii DC } 283\end{array}$ & AHIE00000000 & 5.23 & 4,791 & 65 & 164 & 87.69 & 84.66 & Wang et al. (2012) \\
\hline P. vagans $\mathrm{C} 9-1$ & CP002206 & 4.89 & 4,353 & 4 & 98 & 82.87 & 79.78 & Smits et al. (2010) \\
\hline $\begin{array}{l}\text { P. agglomerans } \\
\text { DSM } 3493^{\mathrm{T}}\end{array}$ & FYAZ00000000 & 4.66 & 4,210 & 33 & 88 & 81.31 & 79.50 & Prakash (unpublished data) \\
\hline P. deleyi $\mathrm{LMG} 24200^{\mathrm{T}}$ & MIPO00000000 & 4.61 & 3,666 & 361 & 737 & 80.37 & 79.45 & Palmer et al. (2017) \\
\hline P. septica LMG $5345^{\mathrm{T}}$ & MLJJ00000000 & 4.31 & 3,898 & 89 & 107 & 80.37 & 78.04 & Palmer et al. (2017) \\
\hline P. cypripedii $\mathrm{LMG} 2657^{\mathrm{T}}$ & MLJI00000000 & 6.55 & 5,914 & 3 & 126 & 80.22 & 77.41 & Palmer et al. (2017) \\
\hline $\begin{array}{l}\text { P. conspicua } \mathrm{LMG} \\
24534^{\mathrm{T}}\end{array}$ & MLFN00000000 & 4.31 & 3,616 & 128 & 388 & 71.16 & 79.92 & Palmer et al. (2017) \\
\hline P. brenneri LMG $5343^{\mathrm{T}}$ & MIEI00000000 & 4.93 & 4,058 & 241 & 532 & 71.03 & 79.70 & Palmer et al. (2017) \\
\hline $\begin{array}{l}\text { P. rwandensis LMG } \\
26275^{\mathrm{T}}\end{array}$ & MLFR00000000 & 5.78 & 5,007 & 69 & 242 & 69.03 & 76.55 & Palmer et al. (2017) \\
\hline P. rodasii DSM $26611^{\mathrm{T}}$ & PIQI00000000 & 5.75 & 5,236 & 31 & 133 & 68.47 & 76.90 & Palmer et al. (2017) \\
\hline P. wallisii $\mathrm{LMG} 26277^{\mathrm{T}}$ & MLFS 00000000 & 4.65 & 3,765 & 149 & 511 & 68.09 & 77.72 & Palmer et al. (2017) \\
\hline
\end{tabular}

${ }^{z}$ The superscript " $T$ " denotes type strain. 
Inoculum suspensions containing $10^{7} \mathrm{ml}^{-1}$ or $10^{4} \mathrm{CFU} / \mathrm{ml}$ were prepared in PBS to investigate the effect of different inoculum concentrations. Plate counting on LB agar plates was used to determine the CFU number as previously described (Tambong et al. 2008). A 100$\mu l$ aliquot from each inoculum concentration was used to inoculate seedlings (five seedlings/inoculum concentrations). For the negative control, five green onion seedlings were inoculated with $100 \mu \mathrm{l}$ of sterile PBS. The seedlings were monitored daily for 21 days. The plants were manually irrigated as required and no fertilizer was applied. To test for the viability of the bacteria-infected tissues, leaves were harvested and chopped in $100 \mu \mathrm{l}$ of PBS and the suspension was plated on LB agar medium. Colony identification was based on morphology (yellow, round with irregular edges) and 16S rRNA amplification using primer pair 16S27 (5'AGAGTTTGATCMTGGCTCAG-3') and 1492R (5'-TACGGY TACCTTGTTACGACTT-3') (Lane 1991) for genus-level identification. Species-level identification was achieved using leuS gene amplification with the LeuS3/LeuS4 primer pair ( $5^{\prime}$ CAGACCGTGCTGGCCAACGARCARGT-3'/5'-CGGCGCGCC CCARTARCGCT-3') (Delétoile et al. 2009) followed by DNA sequencing and BLAST. In addition, DNA sequences of the bacterial colonies were analyzed by phylogenetic tree reconstruction after alignment with the MUSCLE algorithm (Edgar 2004) and maximum likelihood with 1,000 bootstrap replicates as implemented in MEGA6 (Tamura et al. 2013). The pathogenicity experiments were repeated twice.

In addition, the collected tissues were processed and subjected to TaqMan real-time PCR to test the reliability of the developed assay to detect $P$. allii in planta with or without DNA extraction. The collected tissue samples $(50 \mathrm{mg})$ were chopped into pieces $(1 \mathrm{~cm} \times$ $1 \mathrm{~cm}$ ) using a sterile surgical blade, added to $100 \mu \mathrm{l}$ of PBS, and vortexed in order for the bacteria to ooze into the suspension. The approximate bacterial population was determined by culture plating, after serial dilution, of an 100- $\mu$ l aliquot on nutrient agar and incubated at $28^{\circ} \mathrm{C}$ for $48 \mathrm{~h}$. Alternatively, total DNA was extracted from tissues by using the Power Soil DNA isolation kit (MO BIO Laboratories Inc., Carlsbad, CA) according to the manufacturer's recommendations. One microliter of the bacterial suspension obtained from the chopped leaf tissues or purified DNA was subjected to real-time PCR to detect $P$. allii targeting leuS. The samples were run in triplicate in two independent setups and fluorescence was captured as indicated above. Samples were evaluated for TaqMan PCR inhibition using a lambda DNA-based internal control system with the IC-65for/IC-65rev primer pair (5'-TAAAGAGTCGA ATGATGTTGGC-3'/5'-GGTCGCTAATACGCTAAAAGAT-3') and a hex-labeled probe (IC-88pb; 5'-Hex-AAATCACATCGT CACCCATT-BHQ1-3') as previously described (Tambong et al. 2008).

Detection of $P$. allii in spiked and naturally infected onion tissues. The two outermost scales of onion bulbs were discarded and the remaining tissues were cut into pieces of approximately $1 \mathrm{~cm}^{2}$ area. The diced onion tissues $(0.25 \mathrm{~g})$ were spiked, in triplicate, with $100 \mu \mathrm{l}$ of 10 -fold serial dilutions $\left(10^{2}\right.$ to $10^{9}$ $\mathrm{CFU} / \mathrm{ml}$ ) of $P$. allii strain LMG $24248^{\mathrm{T}}$. The spiked onion tissues were transferred into the PowerSoil DNA isolation kit (MO BIO Laboratories Inc.) and homogenized using a Precellys 24 Tissue Homogenizer (Bertin Technologies) with default parameter settings. Total DNA of spiked onion tissues was extracted and eluted in $100 \mu \mathrm{l}$ of DNA-free sterile water following the manufacturer's instructions. Onion tissues not spiked with the bacteria were used as negative controls. Detection of $P$. allii DNA in the spiked onion tissues was done by real-time PCR assay, in triplicate and in two independent experiments, targeting leuS as indicated above using $3 \mu l$ of the total DNA.

The assay was also validated using naturally infected onion plants collected in 2018 in Georgia in the United States. Three onion ( $A$. сера 'Century') scales showing typical water-soaking and tissuediscoloring symptoms were excised from the bulb using a sterile scalpel. Based on the visual disease severity score, eight technical replicates (onion 1: UG-1, UG-1a, and UG-1b; onion 2: UG-2, UG-2a, and UG-2b; and onion 3: UG-3a and UG-3b) were prepared from the bulbs. The tissue (30 mg) was ground in a sterile mortar and pestle using liquid nitrogen. Total DNA of the ground tissue was extracted from each of the eight samples using an UltraClean Microbial DNA Kit (MO BIO Laboratories Inc.) according to the manufacurer's instructions. The extracted DNA were shipped to the Bacteriology Laboratory in Ottawa, Ontario, Canada, and processed with DNA from healthy field onion as a negative control, in triplicate, using the developed TaqMan real-time PCR assay. In parallel, isolation of the Pantoea-like colonies was performed. Symptomatic bulbs were sprayed with $70 \%$ ethanol and wiped with sterile paper towel. Small pieces $\left(4 \mathrm{~mm}^{2}\right)$ of bulb tissue bordering the symptomatic and asymptomatic areas were macerated using a sterile scalpel with a no. 3 blade (DR Instruments, Palos Hills, IL) in $20 \mu \mathrm{l}$ of $0.1 \mathrm{M}$ PBS. Tissue macerates were streaked on nutrient agar plates and incubated for $48 \mathrm{~h}$ at $28^{\circ} \mathrm{C}$. Eight colonies showing typical Pantoea colony morphology and color were purified by restreaking and assayed using the $P$. allii-specific TaqMan real-time PCR reported here. In addition, two Pantoea-like strains (2229 and 2221) isolated from symptomatic onion in Quebec, Canada, were also processed by real-time PCR. All samples were evaluated for PCR inhibition using the lambda DNA-based internal control system indicated above.

Sequence accession numbers. The nucleotide sequences were deposited in the GenBank database with accession numbers MN059882 to MN059888 and MN065819 to MN065825 for 16S rRNA and leuS, respectively.

\section{Results}

Relationship between genome-based ANI and LNI. The draft genome of $P$. allii LMG $24284^{\mathrm{T}}$ (NTMH00000000) obtained in this study has 57 contigs, a size of $5.24 \mathrm{Mb}$ with 4,722 coding sequences, and 159 pseudogenes (Table 2). This sequence was used to compute the ANI values relative to other Pantoea species. ANI values between $P$. allii and the other Pantoea species ranged from 76.55 to 88.65 , whereas LNI values ranged from 68.09 to $89.41 \%$ (Table 2). $P$. allii shared the highest ANI and LNI values with $P$. ananatis ( 88.64 and $89.41 \%$, respectively) and $P$. stewartii ( 84.33 or 84.66 and 88.01 or $87.69 \%$ respectively), depending on the subspecies (Table 2$)$. LNI correlated positively $(\rho=0.8392)$ and significantly $(t=5.3457, d f=12, P<0.001)$ with genome-based ANI. Figure 1 shows a linear relationship between LNI and ANI with a highly significant coefficient of determination, suggesting that nucleotide variations in the 642-bp leuS gene fragment can provide reliable differentiation of $P$. allii from the other Pantoea species.

Verification of primers and probe by BLAST. Figure 2 shows the partial alignment of the leuS gene fragment with the position of the selected primers and probe used in this study. Preliminary evaluation of the two reverse primers identified allii-leuS-235R to be better than allii-leuS-320R based on the consistency of the sigmoidal graph (Fig. 3). Figure 3A shows consistent amplifications (increments in threshold cycle $\left[\mathrm{C}_{\mathrm{T}}\right]$ values of 3.0 to 3.7 ) using primer allii-

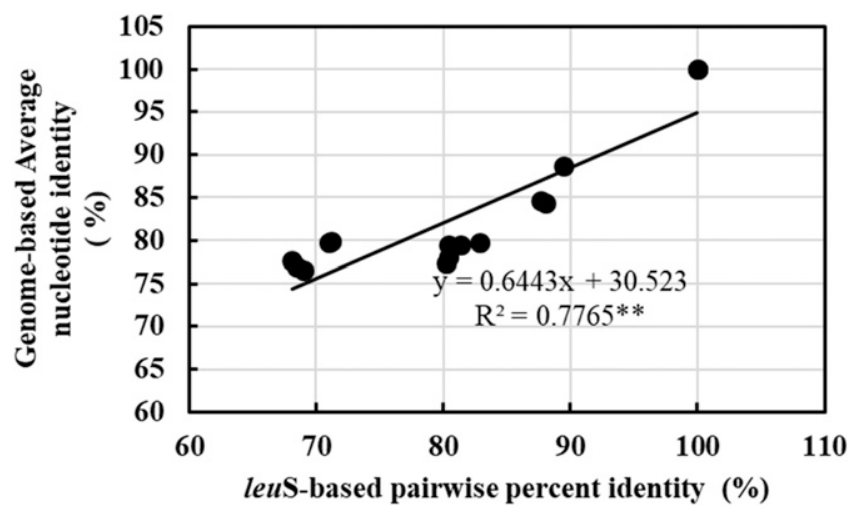

Fig. 1. Plotted values of genome-based average nucleotide identity versus leuS-based pairwise percent identity of Pantoea allii relative 13 other Pantoea species. ${ }^{* \star} P<$ 0.001 . 
leuS235R, with a clear distinction between the serial dilutions of $P$. allii DNA. In contrast, the reverse primer allii-leuS320R exhibited inconsistent fluorescence kinetics (Fig. 3B).

Nucleotide sequences of the primers and probe were analyzed by BLAST to evaluate their specificity. A comprehensive sequence primer-BLAST and BLASTn results confirmed the specificities of the primers and probe. Of the more than 3,300 NCBI bacterial strains analyzed by primer-BLAST for the allii-leuS181F/allii-leuS235R primer set, only $P$. allii LMG $24248^{\mathrm{T}}$ (KF482623) showed a perfect match for the target PCR template. No other bacterial species, including Enterobacter spp., Xanthomonas spp., Pectobacterium spp., and Stenotrophomonas spp., showed target PCR templates. In addition, no target templates were found in over 6,600 fungal blast hits analyzed by primer-BLAST. With respect to BLASTn, for example, the forward primer (allii-leuS181F) showed a perfect hit with only P. allii LMG $24248^{\mathrm{T}}$ (KF482623) with an e-value of 0.002 . The next best hit was Paraburkholderia phytofirmans PsJN (CP001053) at $83 \%$ coverage with an e-value of 0.54 . A similar pattern was observed for the reverse primer (allii-leuS235R), with mannan polymerase complex of Capronia epimyces CBS 606.96 (XM_ $007732321)$ as the closest match with an e-value of 1.6. The probe nucleotide sequence had a perfect match $(100 \%$, e-value $=0.007)$ to the type strain of $P$. allii $\mathrm{LMG} 24248^{\mathrm{T}}$. No significant primer and probe hits were recorded with any other Pantoea species or distant relatives such as Pectobacterium or Erwinia species. In addition, no significant BLAST hits were recorded with over 150 genomes of known bacterial and fungal pathogens of onion.

Sensitivity and specificity of detection of $\boldsymbol{P}$. allii DNA. TaqMan real-time PCR was performed with primer set allii-leuS181F/alliileuS-235R and dual-labeled probe (allii-leuS-205pb) on $P$. allii DNA. Figure $3 \mathrm{~A}$ shows the fluorescence kinetics of the 10-fold serially diluted $P$. allii DNA ( $10 \mathrm{ng}$ to $10 \mathrm{fg}$ ) assayed using the optimized TaqMan real-time PCR assay. The assay exhibited consistent amplification of leuS to $1 \mathrm{pg}$ of $P$. allii DNA (Fig. 3A). The $\mathrm{C}_{\mathrm{T}}$ increased with each DNA dilution and $C_{T}$ value increments of about 3.5 were recorded for each 10-fold dilution of $P$. allii DNA (Fig. 3A and C). A high negative correlation was established between the $\mathrm{C}_{\mathrm{T}}$ values and purified $P$. allii DNA concentration, with a coefficient of determination $\left(r^{2}\right)$ of 0.9901 (Fig. 3C).

The specificity of the TaqMan PCR assay we developed for $P$. allii was evaluated using bacterial strains comprising 34 Pantoea (nine $P$. allii ) and 20 non-Pantoea strains and seven fungal pathogens. The increase in fluorescence crossing the threshold value at a specific cycle indicated positive amplification of the target gene. All $P$. allii strains exhibited a positive detection threshold at a mean $\mathrm{C}_{\mathrm{T}}$ of $20.64 \pm 2.0$ (Fig. 4; Table 3). The presence of the expected band was confirmed by agarose gel electrophoresis (data not shown). Strains $(n=52)$ of the other Pantoea species, non-Pantoea spp., and fungi/oomycetes as well as the negative controls (water) did not record any detectable fluorescence using the TaqMan assay (Fig. 4; Table 3). Processing of blind-coded samples independently verified the reliability and reproducibility of the assay on a different real-time PCR machine at similar $\mathrm{C}_{\mathrm{T}}$ values. Only the blind-coded $P$. allii samples (numbers 1 and 2) gave a positive reaction with a slight difference in the mean $\mathrm{C}_{\mathrm{T}}$ values between Chromo4 (20.64 \pm 2.0$)$ and Rotor-Gene Q (15.32 \pm 0.32$)$. Blind-coded samples of $P$. ananatis (number 3 ) and $P$. stewartii subsp. stewartii (number 4) did not exhibit any detectable fluorescence. These results suggest the specificity of the assay using purified DNA.

Pathogenicity of $P$. allii and real-time PCR detection on infected green onions. Fifteen commercially available green onions were planted and inoculated with $P$. allii under optimal conditions. All $P$. allii-inoculated green onions showed similar yellow discoloration (Supplementary Fig. S1) of the entire inoculated leaf irrespective of the inoculum concentration. No discoloration was observed on PBS-inoculated control plantlets 21 days after inoculation. All total DNA purified or bacterial suspensions from $P$. allii-inoculated green onion plants, 21 days after inoculation, exhibited a positive TaqMan real-time PCR reaction for the presence of $P$. allii (data not shown). The fluorescence kinetic curves generated from all inoculated green onions appeared above the preset $(0.1)$ threshold fluorescence at a mean $C_{T}$ of $30 \pm 2.4$, indicating the presence of the target DNA. $C_{T}$ values obtained without DNA extraction were about three cycles higher than purified DNA. The lambda DNA-based internal control showed a detectable and consistent fluorescence at a mean $\mathrm{C}_{\mathrm{T}}$ value of $14.8 \pm 0.8$, suggesting the absence of significant TaqMan real-time PCR inhibition (data not shown). Twenty-one days after inoculation, the viability of $P$. allii cells in infected onion tissues was verified by colony isolation. Ten Pantoea-like colonies isolated from infected green onions were confirmed to be $P$. allii based on 16S rRNA and leuS analyses. LeuS-phylogeny inference clustered the bacterial isolates from infected green onions within the $P$. allii LMG $24248^{\mathrm{T}}$ clade, which is well supported by $100 \%$ bootstrap values (Fig. 5). All noninoculated plantlets did not show detectable fluorescence.

Detection of $\boldsymbol{P}$. allii in cultures, spiked onion tissues, and naturally infested onion scale samples. The TaqMan real-time PCR we developed reliably detected $P$. allii in 10-fold serial dilutions of 24-h grown cultures to $10^{3} \mathrm{CFU} / \mathrm{ml}$ (30 CFU per reaction) (Fig. 6A). The fluorescence curves of the positive spiked samples appeared above the preset threshold fluorescence of 0.1 (Fig. 6A), an indication of the presence of the target DNA. In addition, the assay accurately

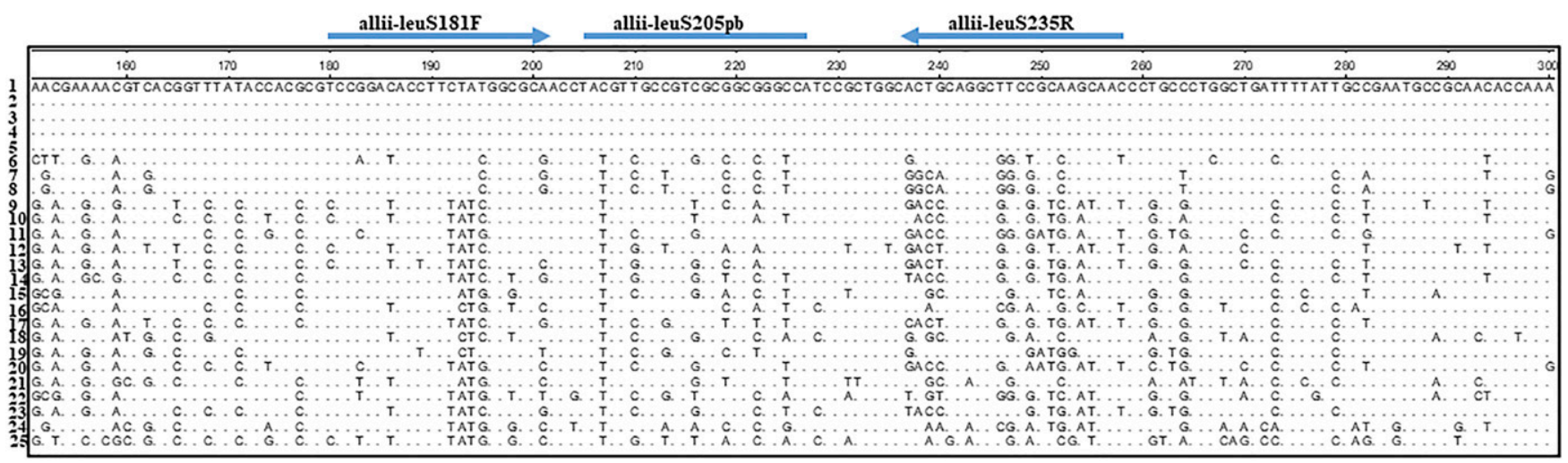

Fig. 2. Alignment of partial leuS nucleotide sequences showing the location of the selected primers and probe sequences and base mismatches. $1=P a n t o e a$ allii $L M G ~ 24248^{\top}$ (KF482623), $2=P$. allii LMG 24202, $3=$ P. allii LMG 24203, $4=P$. allii isolate UG-G1, $5=P$. allii UG-G3, $6=P$. ananatis LMG $2665^{\top}$ (K482626), $7=P$. stewartii subsp. stewartii LMG $2715^{\top}$ (K4826218), $8=P$. stewartii subsp. indologenes LMG $2632^{\top}$ (K482622), $9=P$. agglomerans LMG $1286^{\top}(\mathrm{K} 482638), 10=P$. vagans LMG $24199^{\top}(\mathrm{K} 4826236), 11=P$. gaviniae LMG 25382 ${ }^{\top}$ (K482641), $12=$ P. eucalypti LMG $24197^{\top}$ (K482635), $13=$ P. anthophila LMG 2558 ${ }^{\top}$ (KF482631), $14=P$. deleyi LMG 24200 ${ }^{\top}$ (KF482631), $15=P$. dispersa $^{\top}$ LMG $2603^{\top}$ (KF482630), $16=$ P. cypripedii LMG 2657 ${ }^{\top}$ (KF482629), $17=$ P. brenneri LMG 5343 ${ }^{\top}$ (MIEl00000000), $18=$ P. rodasii DSM 26611 ${ }^{\top}$ (PIQI00000000), $19=P$. septica LMG 5345 ${ }^{\top}$ (KF482640), $20=P$. calida LMG 25383 ${ }^{\top}$ (KF482639), $21=P$. rwandensis LMG 26275 ${ }^{\top}$ (MIFR00000000), $22=P$. wallisii LMG 26277 ${ }^{\top}$ (MLFS00000000), $23=P$. conspicua LMG $24534^{\top}$ (MLFN00000000), $24=$ Tatumella citrea ATCC $31623^{\top}$ (KF482643), $25=$ T. terrea CIP 105600 ${ }^{\top}$ (KF482642). LMG = Laboratium voor Microbiologie at Rijs Universiteit (Gent, Belgium), and ATCC = American Type Culture Collection. 
detected the DNA of $P$. allii in onion samples spiked with $10^{4} \mathrm{CFU} /$ $\mathrm{ml}$ or higher (Fig. 6B). This corresponds to a detection limit of approximately $120 \mathrm{CFU} / \mathrm{g}$ of onion tissue. The assay did not show any detectable fluorescence with unspiked onion tissues and negative control samples (Fig. 6B).

Assay validation was done using naturally infected onion bulbs collected in 2018. All of the onion samples exhibited detectable fluorescence. Six samples (UG-1, UG-1a, UG-1b, UG-2, UG-3a, and UG-3b) showed a mean $\mathrm{C}_{\mathrm{T}}$ at 12.50 (Fig. 7). Two field infested onion samples, UG-2 and UG-2a, had relatively lower $\mathrm{C}_{\mathrm{T}}$ values of 28.10 and 30.56, respectively (Fig. 7). Healthy onion plants and no DNA template used as negative controls did not exhibit any detectable fluorescence (Fig. 7). In addition, all three Pantoea-like colonies obtained from the same onion bulbs gave detectable fluorescence with a mean $\mathrm{C}_{\mathrm{T}}$ value of 19.20, suggesting that these strains could be affiliated taxonomically with $P$. allii. On the contrary, two Pantoea-like strains (2229 and 2221) isolated from diseased onion bulbs
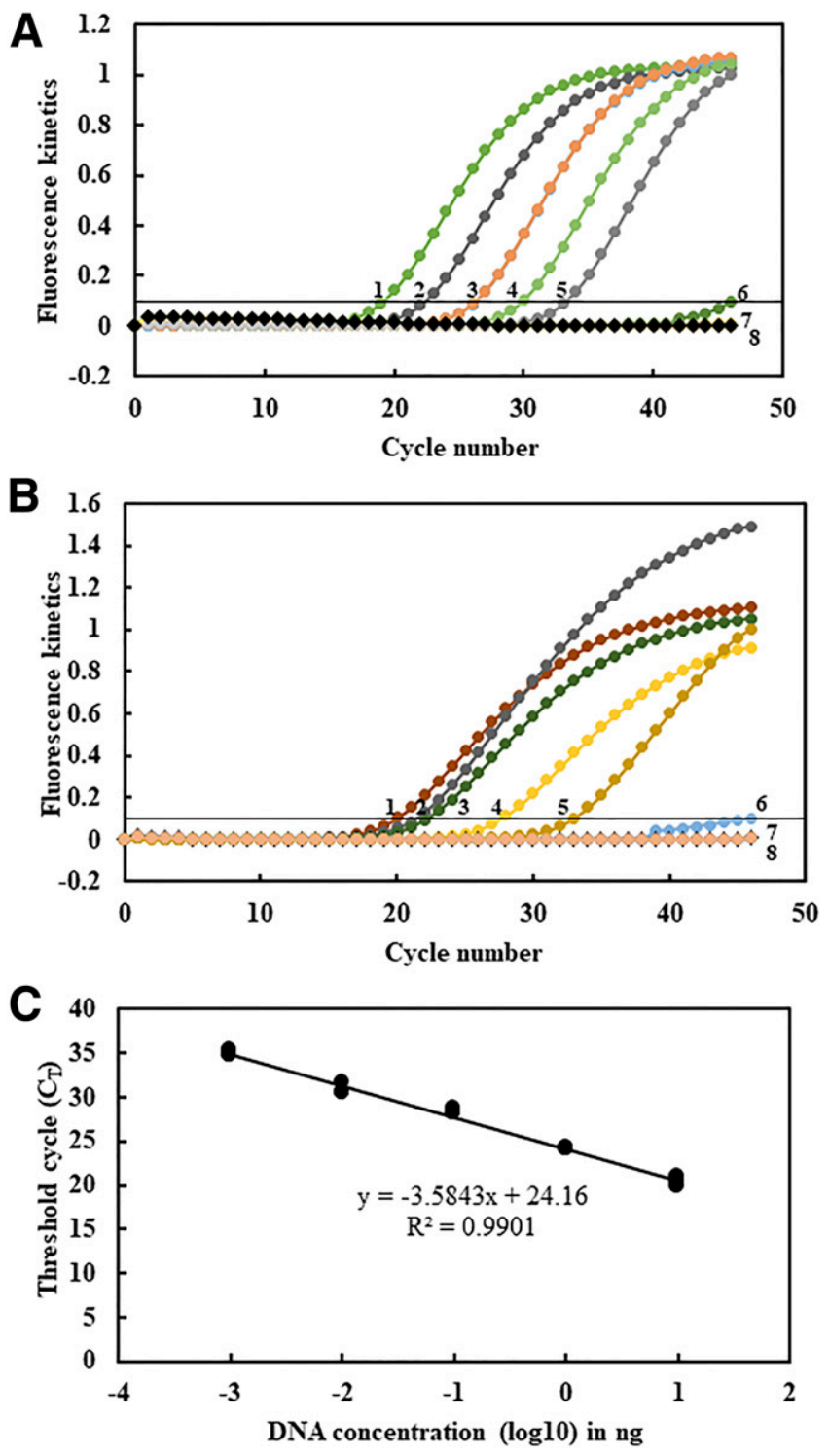

Fig. 3. Consistency and sensitivity of detection of Pantoea allii DNA in 10-fold serial dilutions by TaqMan real-time PCR targeting leuS based on fluorescence kinetics using two reverse primers: A, allii-leuS235R and B, allii-leuS320R. Serial dilutions were as follows: $1=10 \mathrm{ng} / \mu \mathrm{l}, 2=1 \mathrm{ng} / \mu \mathrm{l}, 3=0.1 \mathrm{ng} / \mu \mathrm{l}, 4=0.01 \mathrm{ng} / \mu \mathrm{l}, 5=$ $0.001 \mathrm{ng} / \mu \mathrm{l}, 6=0.0001 \mathrm{ng} / \mu \mathrm{l}, 7=0.00001 \mathrm{ng} / \mu \mathrm{l}$, and $8=$ water blank. $\mathrm{C}$, Standard curve, generated using the allii-leuS181F/allii-leuS235R primer set and probe allii-leuS205pb, showing the log of DNA dilutions and the corresponding threshold cycle. The regression equation and the coefficient of determination $\left(r^{2}\right)$ are indicated. Each dot represents mean data of triplicate TaqMan PCR amplifications of three independent runs. in Quebec, Canada, did not exhibit detectable fluorescence. No PCR inhibition was detected based on the internal control TaqMan realtime PCR assay previously reported (Tambong et al. 2008).

\section{Discussion}

This study reports the development and validation of a TaqMan real-time PCR assay for reliable detection of $P$. allii in pure cultures, artificially infected green onions, and diseased onion bulbs from the field targeting the leuS gene fragment. leuS was targeted because it has high nucleotide variability for differentiation of $P$. allii from other Pantoea species. For example, within this 642-bp leuS gene fragment, $P$. allii differed from $P$. ananatis or $P$. stewartii (its closest phylogenetic relatives) by 68 or 79 nucleotides, respectively. In this study, we demonstrated that a 642-bp leuS gene fragment correlated positively and significantly with a widely used genome-based similarity index, the ANI. This is not surprising, given that our previous study identified leuS as a reliable phylogenetic marker for the genus Pantoea (Tambong et al. 2014).

The TaqMan real-time PCR assay developed here is the first reliable assay for detection of $P$. allii in pure cultures, naturally infected onion bulbs, and artificially inoculated green onions. The only molecular tool reported thus far is that of Figueiredo and PaccolaMeirelles (2012), a conventional PCR assay that differentiates $P$. allii from $P$. ananatis based on agarose gel electrophoretic separation of a 28-nucleotide difference. That assay was designed to detect $P$. ananatis, the causal agent of maize spot disease (Figueiredo and Paccola-Meirelles 2012; Paccola-Meirelles et al. 2001), but caused cross-reactions with $P$. allii. This is not surprising, because $P$. ananatis is phylogenetically the closest species to $P$. allii. The assay developed by Figueiredo and Paccola-Meirelles (2012) could lead to misidentification, given that the published data indicate that 24

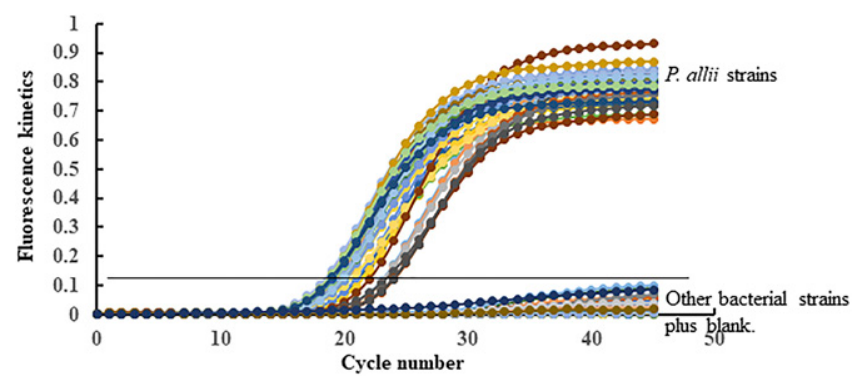

Fig. 4. Fluorescence kinetics showing the specific detection of purified genomic DNA of Pantoea allii strains using TaqMan real-time PCR targeting the leuS gene fragment To note, only strains of $P$. allii exhibited detectable fluorescence above the preset threshold. Nine strains of $P$. allii were run in triplicate and repeated twice.

Table 3. Specificity of detection of purified genomic DNA of Pantoea allii strains using TaqMan real-time PCR targeting the leuS gene fragment

\begin{tabular}{lcc}
\hline Bacterial species/strain & $\begin{array}{c}\text { Strains detected/ } \\
\text { tested, } \boldsymbol{n}(\boldsymbol{\%})\end{array}$ & Mean $\mathbf{C}_{\mathbf{T}} \mathbf{\pm} \mathbf{S D}^{\mathbf{z}}$ \\
\hline Pantoea strains $(n=33)$ & & \\
P. allii & $9 / 9(100)$ & $20.64 \pm 2.0$ \\
Other Pantoea spp. & $0 / 25(100)$ & $\mathrm{N} / \mathrm{A}$ \\
Non-Pantoea $(n=22)$ & $0 / 20(0)$ & \\
Pectobacterium & $0 / 2(0)$ & N/A \\
Xanthomonas & $0 / 3(0)$ & N/A \\
Bacillus & $0 / 2(0)$ & N/A \\
Dickeya & $0 / 2(0)$ & N/A \\
Clavibacter & $0 / 4(0)$ & N/A \\
Pseudomonas & $0 / 4(0)$ & N/A \\
Burkholderia spp. & $0 / 1(0)$ & N/A \\
Streptomyces & $0 / 2(0)$ & N/A \\
Fungi/oomycetes & $0 / 7(0)$ & \\
\hline
\end{tabular}

y Only strains of $P$. allii exhibited detectable fluorescence.

${ }^{\mathrm{z}} \mathrm{C}_{\mathrm{T}}=$ threshold cycle and N/A = not applicable. 
strains of $P$. ananatis exhibit an identical amplicon size of $361 \mathrm{bp}$ as $P$. allii strains. Another inherent problem of conventional PCR assays is that they require post-PCR handling to visualize the results for pathogen identification and as such are prone to errors. The TaqMan real-time PCR assay reported here would minimize these problems, resulting in accurate and reliable detection of $P$. allii.

The primers and probe targeting the leuS gene fragment were specific in differentiating $P$. allii from 51 strains of other Pantoea and non-Pantoea species, including $P$. ananatis, $P$. stewartii subsp. stewartii, and representative strains of the genus Pectobacterium as well as fungal pathogens. The potential high specificity and discriminatory power could be attributable to the six nucleotide mismatches distributed along the length of the probe (Fig. 2). In addition, assay reliability and reproducibility were confirmed on another real-time PCR machine (Rotor-gene; Qiagen) using the same conditions and protocol without optimization. This indicates easy transferability of the assay with consistent results across different laboratories and real-time PCR platforms with minimal adjustments. The slight difference in the mean $\mathrm{C}_{\mathrm{T}}$ values between Chromo4 $(20.64 \pm 2.0)$ and Rotor-Gene Q $(15.32 \pm 0.32)$ could be attributed to differences in the optical fluorescence detection systems required for the range spanning from ultraviolet to infrared wavelengths.

The TaqMan assay sensitivity of $1 \mathrm{pg}$ of $P$. allii DNA compares favorably relative to conventional PCR (Coplin et al. 2002). A similar detection limit has been reported for other bacterial pathogens (Panicker and Bej 2005; Tambong et al. 2016). In addition, the TaqMan assay reliably detected $30 \mathrm{CFU}$ per PCR reaction in pure cultures of $P$. allii. Tambong et al. (2008) reported consistent detection of $10 \mathrm{CFU}$ per reaction of $P$. stewartii by TaqMan realtime assay, whereas Fegan et al. (1998) reported detection of 200 cells of Ralstonia solanacearum using conventional PCR. In $P$. allii-spiked onion tissues, our assay showed reliable detectable fluorescence at a 10-fold lower detection limit (300 CFU per reaction) compared with pure cultures. This could be a result of the inefficiency of the DNA extraction method leading to loss of $P$. allii DNA during processing. Second, the high onion DNA amounts

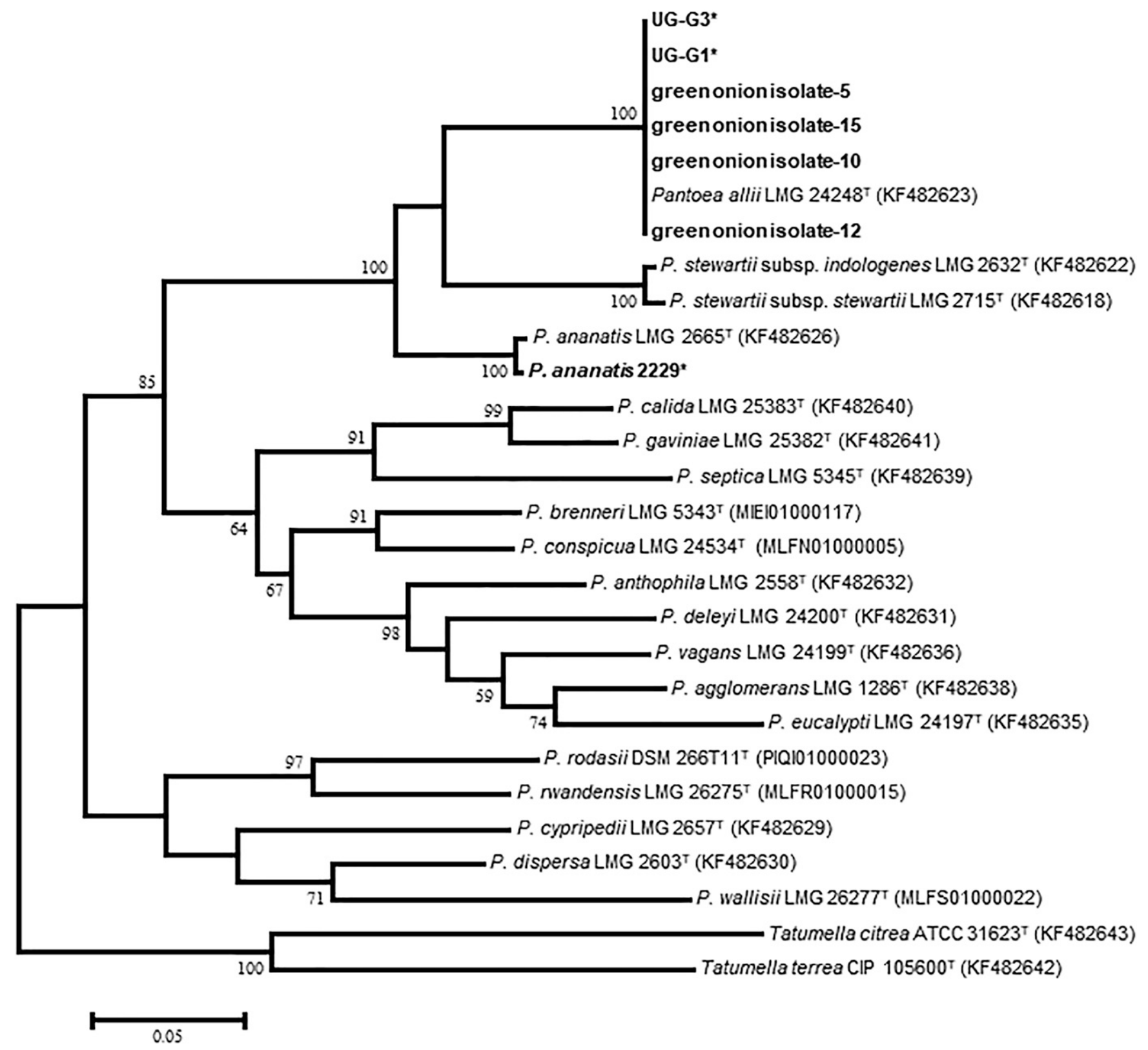

Fig. 5. leuS-phylogenetic tree, with the highest log likelihood $(-4,953.2660)$, of bacterial isolates recovered from Pantoea allii-infected green onions, naturally infested bulb onion, the type strain of $P$. allii LMG $24248^{\top}$, and other Pantoea species, with Tatumella spp. as the outgroup. Maximum likelihood was used with 1,000 bootstrap replicates after sequence alignment using the MUSCLE algorithm (Edgar 2004) as implemented in MEGA6 (Tamura et al. 2013). Bootstrap values below $50 \%$ are not shown. Only four of the 10 colonies isolated from infected green onions and identified as $P$. allii as well as two isolates from field bulb onion are used in the phylogenetic analysis. Asterisks indicate $P$. allii strains isolated in 2018 from naturally infested onion bulbs. 
could physically interfere with the amplification of the relatively low $P$. allii DNA in the samples. However, based on the data from lambda internal control assays, only minimal and nonsignificant PCR inhibition was observed.

The assay was validated using naturally diseased onion bulbs. All field diseased onion samples with typical symptoms exhibited detectable fluorescence within the acceptable $\mathrm{C}_{\mathrm{T}}$ range $(<35$ cycles). However, samples UG-1, UG-1a, UG-1b, UG-2, UG-3a, and UG-3b had similar mean $C_{T}$ values that were about 16 or 18 cycles lower than the mean $C_{T}$ values of samples UG-2a and UG-2b, respectively. The low $\mathrm{C}_{\mathrm{T}}$ values indicate high amounts of $P$. allii DNA, consistent with a high number of $P$. allii cells in the sample. Interestingly, samples UG-2 (mean $\left.\mathrm{C}_{\mathrm{T}}=12.50\right)$, UG-2a (mean $\mathrm{C}_{\mathrm{T}}=$ 28.10), and UG-2b (mean $C_{T}=30.56$ ) are replicates of the same diseased onion bulb but differ in their mean $\mathrm{C}_{\mathrm{T}}$ values, suggesting differences in the amount of $P$. allii DNA in these replicates. This could indicate a nonuniform colonization of a diseased onion bulb by $P$. allii, which may be expected in samples from the field. Based on the standard curve (data not shown) derived from spiked onion tissues, the population densities on naturally infected onions ranged from $1.35 \times 10^{5}$ to $11.7 \times 10^{9} \mathrm{CFU} / \mathrm{ml}$. Sample UG- $2 \mathrm{~b}$ had the lowest density of $1.35 \times 10^{5} \mathrm{CFU} / \mathrm{ml}$. This density is close to the detection limit $\left(10^{5} \mathrm{CFU} / \mathrm{ml}\right)$ of the assay and thus is prone to some variability as a result of pipetting. This might explain why one of the replicates showed a slightly high $\mathrm{C}_{\mathrm{T}}$ value. However, the $\mathrm{C}_{\mathrm{T}}$ value of this replicate is still below the cutoff value for accurate and reliable $P$. allii detection using the assay. These data on differential $\mathrm{C}_{\mathrm{T}}$ values indicate that the real-time PCR assay reported here could be used to determine the relative abundance of the pathogen
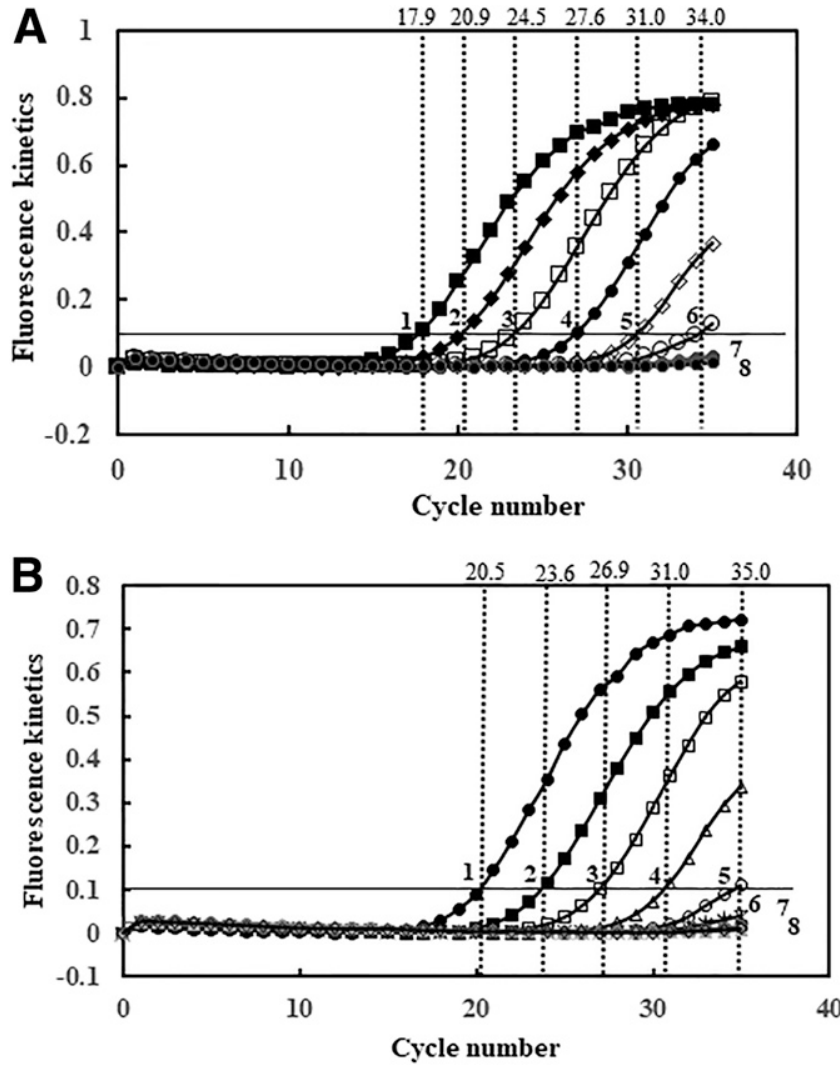

Fig. 6. A, Sensitivity of detection of serially diluted Pantoea allii cultures and B, spiked onion tissues followed by total DNA extraction by TaqMan real-time assay targeting leuS. Mean viable plate counts were as follows: sample $1=10^{8} \mathrm{CFU} / \mathrm{ml}$, sample 2 $=10^{7} \mathrm{CFU} / \mathrm{ml}$, sample $3=10^{6} \mathrm{CFU} / \mathrm{ml}$, sample $4=10^{5} \mathrm{CFU} / \mathrm{ml}$, sample $5=10^{4}$ $\mathrm{CFU} / \mathrm{ml}$, sample $6=10^{3} \mathrm{CFU} / \mathrm{ml}$, sample $7=10^{2} \mathrm{CFU} / \mathrm{ml}$, and sample $8=$ negative control (autoclaved Milli- $Q$ water) or unspiked onion tissue. Three microliters of the bacterial suspension or total DNA was assayed by TaqMan realtime PCR. The mean threshold values are given above the graph. The data are means of three independent runs. in plant tissues or the environment. The presence of viable $P$. allii cells in all of the diseased onions was confirmed by colony isolation and identification by DNA sequencing and detection by real-time PCR.

Testing of two Pantoea-like strains from diseased onion bulbs in Quebec did not yield a detectable fluorescence. Further taxonomic characterization based on 16S rRNA and leuS genes identified strain 2229 to be $P$. ananatis, whereas strain 2221 could be affiliated with Kosakonia cowanii with high confidence. The genus Kosakonia is one of the closest genera to genus Pantoea. This explains why these two strains did not exhibit a positive reaction with the real-time PCR assay reported here.

The TaqMan assay detected DNA of $P$. allii in all artificially inoculated green onions, 21 days after inoculation. The growth of bacteria ( $>10^{6} \mathrm{CFU} / \mathrm{g}$ ) on LB confirms the viability of $P$. allii cells in tissues of green onion leaves 21 days after inoculation, suggesting that the green onion tissues provide a stable environment for multiplication and disease induction. The mode of transmission of this pathogen is still to be unraveled. However, $P$. allii-contaminated onion seeds and soil could be potential sources of propagation of the disease. This TaqMan assay could be used to detect the presence of $P$. allii in diverse sample types.

The reported TaqMan assay targeting leuS is highly reproducible and compares favorably to the only conventional PCR assay reported by Figueiredo and Paccola-Meirelles (2012). Our assay offers real-time monitoring of the targeted leuS amplicon with high specificity and no postamplification handling, thus minimizing sources of error and misidentification. In addition, the real-time PCR technique is robust and can be automated with potential highthroughput analysis of up to 96 samples (Tambong et al. 2008). Real-time PCR also offers the possibility of multiplexing for multiple pathogen detection in onions or Allium species. This study also showed, for the first time, that $P$. allii can cause yellow discolorations on green onion leaves. This could reduce the marketable value of the harvest, with potential income loss to onion growers. Because $P$. allii-incited diseases have not been reported in Canada, precautionary measures are needed to minimize the introduction of the pathogen through imported onions. The TaqMan assay validated in this study could be useful to regulatory agencies for screening onion imports for the presence of $P$. allii.

\section{Acknowledgments}

We thank Dr. R. Walcott, Dr. A. Vidaver, A. Dionne, and Dr. S. H. de Boer for kindly providing some of the bacterial strains, and we thank C.A. Levesque and A. Fessehaie for providing some of the genomic DNA. We are grateful to Shea Miller and Miao Liu for reviewing the draft manuscript.

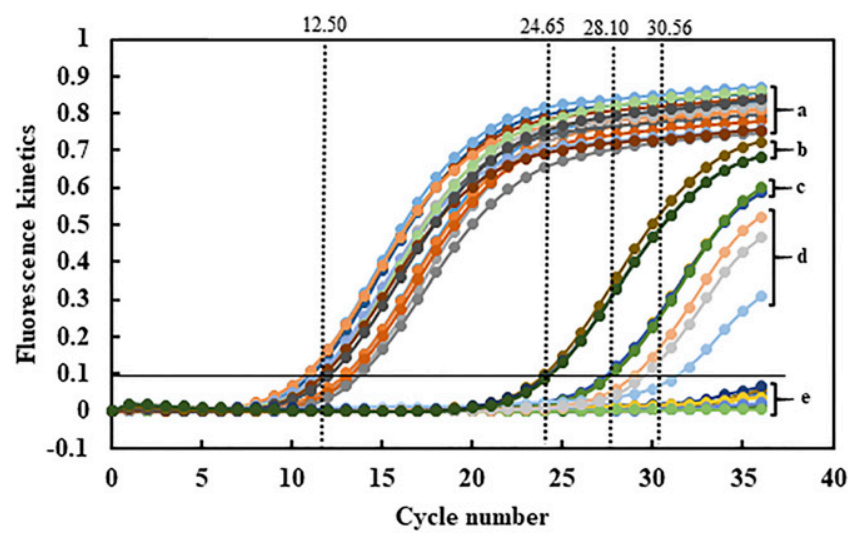

Fig. 7. Detection of Pantoea allii LMG $24248^{\top}$ in naturally infested onion bulb tissues by TaqMan real-time PCR targeting leuS. Lowercase letters indicate the following: $a=$ infested onion samples UG-1, UG-1a, UG-1b, UG-2, UG-3a, and UG-3b; $b=$ positive control ( $0.1 \mathrm{ng}$ of $P$. allii DNA); c = infested onion sample UG-2a; $\mathrm{d}=$ infested onion sample UG-2b; and $\mathrm{e}=$ healthy onion and negative control (no $P$. allii DNA). The mean threshold values are given above the graph. The data are means of three independent runs. 


\section{Literature Cited}

Adam, Z., Tambong, J. T., Lewis, C. T., Lévesque, C. A., Chen, W., Bromfield, E. S. P., Khan, I. U. H., and Xu, R. 2014. Draft genome sequence of Pantoea ananatis strain $\mathrm{LMG} 2665^{\mathrm{T}}$, a bacterial pathogen of pineapple fruitlets. Genome Announc. 2:e00489-14.

Agriculture and Agri-Food Canada. 2012. Crop profile for Allium vegetables in Canada, 2012. http://www.agr.gc.ca/pmc-cropprofiles

Altschul, S. F., Gish, W., Miller, W., Myers, E. W., and Lipman, D. J. 1990. Basic local alignment search tool. J. Mol. Biol. 215:403-410.

Brady, C. L., Cleenwerck, I., Venter, S. N., Engelbeen, K., De Vos, P., and Coutinho, T. A. 2010. Emended description of the genus Pantoea, description of four species from human clinical samples, Pantoea septica sp. nov., Pantoea eucrina sp. nov., Pantoea brenneri sp. nov. and Pantoea conspicua sp. nov., and transfer of Pectobacterium cypripedii (Hori 1911) Brenner et al. 1973 emend. Hauben et al. 1998 to the genus as Pantoea cypripedii comb. nov. Int. J. Syst. Evol. Microbiol. 60:2430-2440.

Brady, C. L., Goszczynska, T., Venter, S. N., Cleenwerck, I., De Vos, P., Gitaitis, R. D., and Coutinho, T. A. 2011. Pantoea allii sp. nov., isolated from onion plants and seed. Int. J. Syst. Evol. Microbiol. 61:932-937.

Coplin, D. L., Majerczak, D. R., Zhang, Y., Kim, W.-S., Jock, S., and Geider, K. 2002. Identification of Pantoea stewartii subsp. stewartii by PCR and strain differentiation by PFGE. Plant Dis. 86:304-311.

Delétoile, A., Decré, D., Courant, S., Passet, V., Audo, J., Grimont, P., Arlet, G., and Brisse, S. 2009. Phylogeny and identification of Pantoea species and typing of Pantoea agglomerans strains by multilocus gene sequencing. J. Clin. Microbiol. 47:300-310.

Edens, D. G., Gitaitis, R. D., Sanders, F. H., and Nischwitz, C. 2006. First report of Pantoea agglomerans causing a leaf blight and bulb rot of onions in Georgia. Plant Dis. 90:1551.

Edgar, R. C. 2004. MUSCLE: Multiple sequence alignment with high accuracy and high throughput. Nucleic Acids Res. 32:1792-1797.

Fegan, M., Holoway, G., Hayward, A. C., and Timmis, J. 1998. Development of a diagnostic test based on the polymerase chain reaction (PCR) to identify strains of Ralstonia solanacearum exhibiting the biovar 2 genotype. Pages 34-43 in: Bacterial Wilt Disease: Molecular and Ecological Aspects. P. H.Prior, C. Allen, and J. G. Elphinstone, eds. Springer-Verlag, Berlin, Germany.

Figueiredo, J. E. F., and Paccola-Meirelles, L. D. 2012. Simple, rapid and accurate PCR-based detection of Pantoea ananatis in maize, sorghum and Digtaria sp. J. Plant Pathol. 94:663-667.

Gitaitis, R. D., and Gay, J. D. 1997. First report of a leaf blight, seed stalk rot, and bulb decay of onion by Pantoea ananas in Georgia. Plant Dis. 81:1096.

Goszczynska, T., Moloto, V. M., Venter, S. N., and Coutinho, T. A. 2006. Isolation and identification of Pantoea ananatis from onion seed in South Africa. Seed Sci. Technol. 34:655-668.

Hattingh, M. J., and Walters, D. F. 1981. Stalk and leaf necrosis of onion caused by Erwinia herbicola. Plant Dis. 65:615-618.

Lane, L. D. 1991. 16S/23S rRNA sequencing. Pages 115-175 in: Nucleic Acid Techniques in Bacterial Systematics. E. Stackebrandt and M. Goodfellow, eds. John Wiley \& Sons Ltd., Chichester, UK.

Opara, L. U. 2003. ONIONS: Post-Harvest Operations. AGST/FAO Technical publication. D. Mejia, ed. http://www.fao.org/3/a-av011e.pdf

Paccola-Meirelles, L. D., Ferreira, A. S., Meirelles, W. F., Marriel, I. E., and Casela, C. R. 2001. Detection of a bacterium associated with a leaf spot disease of maize in Brazil. J. Phytopathol. 149:275-279.

Palmer, M., Steenkamp, E. T., Coetzee, M. P. A., Chan, W. Y., van Zyl, E., De Maayer, P., Coutinho, T. A., Blom, J., Smits, T. H. M., Duffy, B., and Venter, S. N. 2017. Phylogenomic resolution of the bacterial genus Pantoea and its relationship with Erwinia and Tatumella. Antonie van Leeuwenhoek 110:1287-1309.
Panicker, G., and Bej, A. K. 2005. Real-time PCR detection of Vibrio vulnificus in oysters: Comparison of oligonucleotide primers and probes targeting $v v h \mathrm{~A}$. Appl. Environ. Microbiol. 71:5702-5709.

R Core Team. (2014). R: A Language and Environment for Statistical Computing. R Foundation for Statistical Computing, Vienna, Austria. http://www.Rproject.org/

Robène, I., Perret, M., Jouen, E., Escalon, A., Maillot, M. V., Chabirand, A., Moreau, A., Laurent, A., Chiroleu, F., and Pruvost, O. 2015. Development and validation of a real-time quantitative PCR assay to detect Xanthomonas axonopodis pv. allii from onion seed. J. Microbiol. Methods 114:78-86.

Smits, T. H., Rezzonico, F., Kamber, T., Goesmann, A., Ishimaru, C. A., Stockwell, V. O., Frey, J. E., and Duffy, B. 2010. Genome sequence of the biocontrol agent Pantoea vagans strain C9-1. J. Bacteriol. 192: 6486-6487.

Tambong, J. T., de Cock, A. W., Tinker, N. A., and Levesque, C. A. 2006. Oligonucleotide array for identification and detection of Pythium species. Appl. Environ. Microbiol. 72:2691-2706.

Tambong, J. T., Mwange, K. N., Bergeron, M., Ding, T., Mandy, F., Reid, L. M., and Zhu, X. 2008. Rapid detection and identification of the bacterium Pantoea stewartii in maize by TaqMan real-time PCR assay targeting the cpsD gene. J. Appl. Microbiol. 104:1525-1537.

Tambong, J. T., Xu, R., Daayf, F., Briere, S., Bilodeau, G. J., Tropiano, R., Hartke, A., Reid, L. M., Cott, M., Cote, T., and Agarkova, I. 2016. Genome analysis and development of a multiplex TaqMan real-time PCR for specific identification and detection of Clavibacter michiganensis subsp. nebraskensis. Phytopathology 106:1473-1485.

Tambong, J. T., Xu, R., Kaneza, C. A., and Nshogozabahizi, J. C. 2014. An in-depth analysis of a multilocus phylogeny identifies leuS as a reliable phylogenetic marker for the genus Pantoea. Evol Bioinform 10: $115-125$.

Tamura, K., Stecher, G., Peterson, D., Filipski, A., and Kumar, S. 2013. MEGA6: Molecular Evolutionary Genetics Analysis version 6.0. Mol. Biol. Evol. 30: 2725-2729.

Thompson, J. D., Higgins, D. G., and Gibson, T. J. 1994. CLUSTAL W: Improving the sensitivity of progressive multiple sequence alignment through sequence weighting, position-specific gap penalties and weight matrix choice. Nucleic Acids Res. 22:4673-4680.

Walcott, R. R., Gitaitis, R. D., Castro, A. C., Sanders, F. H. J., and Diaz-Perez, J. C. 2002. Natural infestation of onion seed by Pantoea ananatis, causal agent of center rot. Plant Dis. 86:106-111.

Wang, X., Yang, F., and von Bodman, S. B. 2012. The genetic and structural basis of two distinct terminal side-branch residues in stewartan and amylovoran exopolysaccharides and their potential role in host adaptation. Mol. Microbiol. 83:195-207.

Weller, S. A., Elphinstone, J. G., Smith, N. C., Boonham, N., and Stead, D. E. 2000. Detection of Ralstonia solanacearum strains with a quantitative, multiplex, real-time, fluorogenic PCR (TaqMan) assay. Appl. Environ. Microbiol. 66:2853-2858.

$\mathrm{Xu}, \mathrm{R}$., and Tambong, J. T. 2011. TaqMan real-time PCR assay targeting the cytochrome o ubiquinol oxidase subunit II gene for detection of several pathovars of Pseudomonas syringae. Can. J. Plant Pathol. 33:318-331.

Ye, J., Coulouris, J., Zaretskaya, I., Cutcutache, I., Rozen, S., and Madden, T. L. 2012. Primer-BLAST: A tool to design target-specific primers for polymerase chain reaction. BMC Bioinformatics 13:134.

Yoon, S. H., Ha, S. M., Lim, J. M., Kwon, S. J., and Chun, J. 2017. A large-scale evaluation of algorithms to calculate average nucleotide identity. Antonie van Leeuwenhoek 110:1281-1286. 